\title{
Does lower gastrointestinal endoscopy during pregnancy pose a risk for mother and child? - a systematic review
}

\author{
Alison De Lima ${ }^{1 *}$, Boris Galjart ${ }^{1}$, Pieter HA Wisse', Wichor M Bramer ${ }^{2}$ and C Janneke van der Woude ${ }^{1}$
}

\begin{abstract}
Background: Gastrointestinal endoscopy plays a crucial role in the diagnosis and management of gastrointestinal disorders. When endoscopy is indicated during pregnancy, concerns about the effects on pregnancy outcome often arise. The aim of this study was to assess whether lower gastrointestinal endoscopies (LGEs) across all three trimesters of pregnancy affects pregnancy outcomes.
\end{abstract}

Methods: A systematic literature search was performed using Embase (including MEDLINE), Medline OvidSP, Cochrane Central Register of Controlled Trials, Web-of-Science, Google scholar and Pubmed. All original research articles from 1990 until May 2014 involving pregnant women who underwent LGE for any indication were included. Adverse pregnancy events like spontaneous abortion, preterm birth and fetal demise were assessed for a temporal and etiological relation with the LGE.

Results: In total, 5514 references were screened by two independent reviewers. Eighty-two references met the inclusion criteria and were selected. Two retrospective, controlled studies, one uncontrolled study and 79 case reports were identified. In the three studies, birth outcomes did not differ between women undergoing LGE during pregnancy, compared to women that had an indication for LGE but in whom LGE was not performed because of pregnancy. In 79 case reports, 92 patients are described who underwent 100 LGE's during pregnancy. LGEs performed in all trimesters ( $n=32,39$ and 29) were both temporally and etiologically related to 1, 3 and 2 adverse events, respectively.

Conclusion: Based on the available literature, this review concludes that lower gastrointestinal endoscopy during pregnancy is of low risk for mother and child in all three trimesters of pregnancy.

Keywords: Endoscopy, Pregnancy, Colonoscopy, Sigmoidoscopy

\section{Background}

Gastrointestinal endoscopy plays a crucial role in the diagnosis and management of acute and chronic gastrointestinal disorders. In general, sigmoidoscopy and colonoscopy are regarded of low risk, because of the very low rate of serious complications following lower gastrointestinal endoscopy (LGE) [1,2]. Endoscopic procedures during pregnancy are less common, and although an estimated 6000 pregnant women in the United States annually have an indication for endoscopy, the safety of endoscopy during pregnancy remains unknown [3].

\footnotetext{
* Correspondence: a.delima@erasmusmc.nl

'Department of Gastroenterology and Hepatology, Erasmus MC - University Medical Center Rotterdam, 's Gravendijkwal 230, Room Hs-306, 3015 CE Rotterdam, The Netherlands

Full list of author information is available at the end of the article
}

LGE during pregnancy raises important safety questions, including whether medication or bowel preparation is associated with placental abruption or fetal trauma during endoscopic intubation [4] and fetal demise due to maternal hypoxia [4], hypotension or cardiac arrhythmias [5]. Despite the paucity of data, oesophagoduodenoscopy [6,7] and sigmoidoscopy [8] are considered relatively safe during pregnancy. The safety of colonoscopy during pregnancy remains more elusive and under debate. In recent ASGE guidelines LGE is regarded of low risk during pregnancy, and it is concluded that if possible this should be deferred to the second trimester [9]. Recently, we had to perform several endoscopies in other trimesters and therefore we decided to perform a systematic literature search to assess the effect of the timing of LGE during pregnancy on 
adverse pregnancy outcomes like spontaneous abortion, stillbirth and premature labor.

\section{Methods}

\section{Search strategy}

A systematic database search for citations about LGE during pregnancy was performed by the first author (ADL) and an information specialist (WMB) on May 26th 2014. This search was performed in the following databases: Embase (including MEDLINE), Medline OvidSP, Cochrane Central Register of Controlled Trials, Web-of-Science, Google scholar and Pubmed. The detailed digital search strategy is provided in the Additional file 1.

\section{Review and study selection process}

Titles and abstracts identified through the search strategy were assessed by two independent reviewers for potential eligibility. All original research articles, including case reports, were included. References were excluded on title and abstract based on the following exclusion criteria: all references published before 1990, all references not in English, all references regarding different subjects, conference proceedings and animal studies. Disagreements were settled in consensus and, if necessary, after discussion with a third independent reviewer. The manuscripts deemed potentially eligible for inclusion were obtained for full text review. The full texts were assessed by the two independent reviewers ((1) ADL and (2) BG and PHAW), using pre-defined eligibility criteria. Articles were included when the study population consisted of at least one pregnant female and LGE was performed during pregnancy. Articles on ectopic pregnancy were excluded, as well as articles without outcome information on the mother and the child. Discussions with the third independent (CJW) reviewer were used to resolve disagreements.

\section{Data extraction}

Data from the eligible reports was extracted using a standardized form by the primary reviewers. Differences in the extracted data were resolved through consensus or, if necessary, discussion with the third independent reviewer. For each study, the following data was extracted considering the following:

1. Procedure (type of endoscopy, gestational week of endoscopy)

2. Participants (including age, indication for endoscopy)

3. Interventions (additional surgery, medical treatment, gestational week of other interventions)

4. Outcomes (including birth outcomes, fetal adverse events, maternal adverse events, gestational week of adverse events)

\section{Definitions}

Sigmoidoscopy was defined as endoscopic intubation no further than the splenic flexure, and colonoscopy was defined as endoscopic intubation beyond the splenic flexure.

Miscarriages or spontaneous abortion were defined as fetal loss prior to 20th gestational week. Stillbirth or fetal demise was defined as fetal loss beyond the 20th gestational week. Premature delivery was defined as delivery before gestational week 37 .

A temporal relation between an adverse event and LGE was found as plausible if the adverse event occurred within 1 week of the LGE and defined as unlikely when the adverse event occurred more than 1 week after endoscopy.

An etiological relation was found plausible if a temporal relation existed and, in addition, based on sound, medical reasoning the adverse event could be linked to the LGE. Etiological relations were classified on an ordinal scale as: unlikely, possible, probable and likely. These relations were determined in consensus, based on the following definitions.

Unlikely relation: LGE or its preparation or sedation cannot explain maternal/fetal adverse event, based on sound, medical reasoning. Elective abortions and induced labor or elective caesarean sections were all classified as unlikely related to LGE.

Possible relation: LGE or its preparation or sedation could explain maternal/fetal adverse event, however in between LGE and the occurrence of the adverse event another intervention was also performed (e.g. laparotomy).

Probable relation: LGE or its preparation or sedation could explain maternal/fetal adverse event, no other interventions between LGE and adverse event were performed, however, the underlying maternal disease could still also explain the adverse event.

Likely relation: LGE or its preparation or sedation could explain maternal/fetal adverse event, no other interventions between adverse event were performed, maternal disease does not seem etiologically related to the adverse event.

\section{Results}

The search yielded a total of 5514 citations. After reviewing title and abstracts, 980 manuscripts were selected for further review. After review of the full text, 75 articles were included, including one retrospective uncontrolled study, two retrospective, controlled studies and 72 case reports or series. An additional non-systematic search yielded another 7 case reports, resulting in a total of 82 articles (See flowchart in Figure 1).

\section{Description of the studies}

An uncontrolled, retrospective, multicenter study in 1995 [10], which was published again one year later as an 


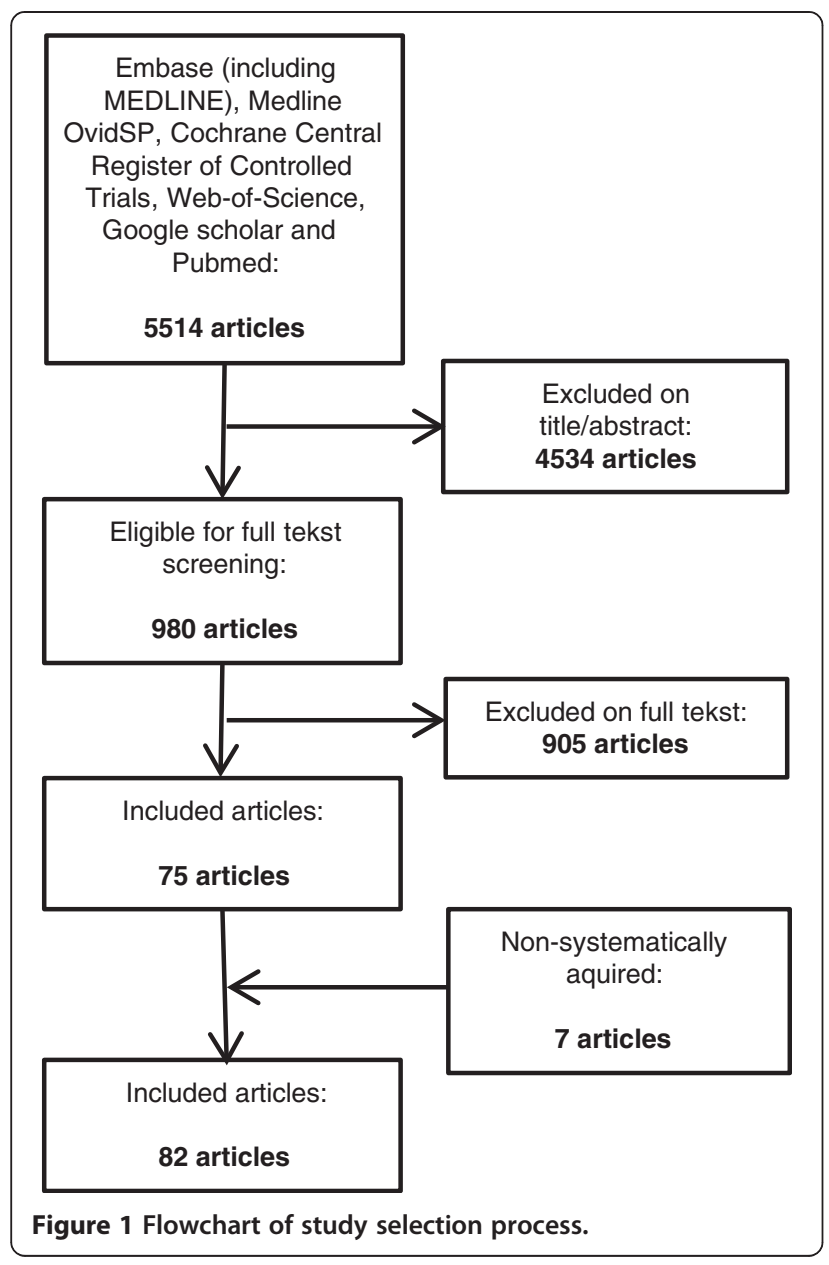

expanded cohort with added controls [8], reported 46 pregnant patients undergoing 48 sigmoidoscopies and 8 pregnant patients undergoing 8 colonoscopies. There were no differences in birth outcomes between the pregnant patients undergoing endoscopy during pregnancy compared to the pregnant patients not undergoing endoscopy during pregnancy. Both groups had similar indications for endoscopy. In addition, there were no differences in birth outcomes compared to the national American rates at that time. No adverse maternal events were reported following endoscopy. Following sigmoidoscopy, 4 voluntary abortions and 3 fetal demises occurred. All fetal demises were temporally and etiologically unrelated with the endoscopies. Following colonoscopy, there was one voluntary abortion and one fetal demise, both also temporally and etiologically unrelated with the colonoscopy.

In 2010, a study focusing exclusively on colonoscopies during pregnancy was published [3]. This retrospective, controlled cohort study reported on the safety and efficacy of colonoscopy in 20 pregnant patients. These pregnant patients were matched 1:1 with 20 pregnant controls with the same indication for colonoscopy but who did not undergo colonoscopy due to pregnancy.
The study group was also compared to the pregnancy outcomes of the American national average. The majority of colonoscopies were performed in the second trimester of pregnancy $(n=16)$, with only 2 colonoscopies performed in respectively the first and third trimester. The study group trended towards worse pregnancy outcomes like stillbirth, premature delivery, low birth weight, low APGAR score, congenital defects and infant death after live birth, compared to the American national average. These nonsignificant differences can be attributed to the underlying illness in the study group according to the authors. When compared to the control group as described above, the study group tended to have slightly better fetal outcomes compared to the control group in terms of premature delivery, low birth weight, APGAR scores, congenital defects, neonatal ICU stay, infant postpartum hospitalization and infant death after live birth.

\section{Description of the case reports}

The 79 case reports describing 92 patients are summarized and categorized per trimester in Tables 1, 2 and 3.

\section{Indications for LGE}

Roughly, five major indications for endoscopy could be distinguished: (1) IBD and other colitis, (2) malignancy, (3) volvulus or incarcerated uterus, (4) non-malignant colonic obstruction and (5) gastrointestinal bleeding.

\section{Adverse events related to $L G E$}

All temporally and etiologically related adverse events identified from the case reports are summarized in Table 4.

\section{First trimester}

In the first trimester, 32 LGEs were performed in 30 patients. All complications following LGE in the first trimester are listed in Table 1. Three adverse events occurred within 1 week of the LGE. In one case report [20], the patient underwent sigmoidoscopy at gestational week 10 and the patient had an incomplete spontaneous abortion at 10.4 weeks. The patient suffered from severe rectal bleeding due to a heterotopic, abdominal pregnancy protruding the terminal ileum. This adverse event could possibly be attributed to the LGE, because this patient also underwent laparotomy after the LGE and suffered from severe gastrointestinal bleeding. The other two temporally related adverse events in the first trimester were both elective abortions, and were therefore classified as etiologically unrelated to the LGE $[17,18]$.

\section{Second trimester}

In the second trimester, 39 endoscopies were performed in 35 patients. All complications following LGE in the second trimester are listed in Table 2. Six adverse events occurred within one week of LGE. Three cases reported 
Table 1 First trimester fetal and maternal adverse events (wk 1-12)

\begin{tabular}{|c|c|c|c|c|c|c|c|}
\hline Indication & $\mathrm{N}$ & $\begin{array}{l}\text { Maternal adverse } \\
\text { events }\end{array}$ & $\begin{array}{l}\text { Pregnancy } \\
\text { outcome }\end{array}$ & $\begin{array}{l}\text { Spontaneous } \\
\text { abortion }\end{array}$ & Other fetal adverse events & $\begin{array}{l}\text { Temporal relation with } \\
\text { endoscopy? }\end{array}$ & $\begin{array}{l}\text { Etiological relation with } \\
\text { endoscopy? }\end{array}$ \\
\hline \multicolumn{8}{|l|}{ Sigmoidoscopy } \\
\hline IBD \& colitis other [11-16] & 6 & None & Live birth $(n=6)$ & No $(n=6)$ & $\begin{array}{l}3 \text { premature births } \\
(34,28 \text { and } 25.5 \text { wks })\end{array}$ & No & No \\
\hline Malignancy $[17,18]$ & 3 (in 2 pts) & None & Elective abortion $(n=2)$ & No $(n=2)$ & $\begin{array}{l}\text { Elective abortion } \\
\text { (unwanted pregnancies) }\end{array}$ & Yes $(n=2)$ & No \\
\hline Volvulus and incarcerated uterus [19] & 1 & None & No pregnancy losses & No $(n=1)$ & Not reported & No & No \\
\hline Non-malignant colonic obstruction & 0 & - & - & - & - & - & - \\
\hline Gastrointestinal bleeding [20] & 1 & None & $\begin{array}{l}\text { Incomplete } \\
\text { abortion }(n=1)\end{array}$ & $\begin{array}{l}\text { Yes, incomplete } \\
\text { abortion at } 10.4 \\
\text { wks }(n=1)\end{array}$ & - & Yes & $\begin{array}{l}\text { Possible, abdominal } \\
\text { pregnancy, laparotomy } \\
\text { after sigmoidoscopy }\end{array}$ \\
\hline \multicolumn{8}{|l|}{ Colonoscopy } \\
\hline IBD \& colitis other [21-27] & 12 & None & $\begin{array}{l}\text { Live births }(n=11) \text {, } \\
\text { stillbirth }(n=1)\end{array}$ & No $(n=12)$ & $\begin{array}{l}2 \text { premature births ( } 32 \\
\text { and } 33 \text { wks), } 1 \text { stillbirth } \\
(22 \text { wks) }\end{array}$ & $\begin{array}{l}\text { Unclear, paper fails to } \\
\text { show which outcome } \\
\text { belongs to which patient }\end{array}$ & $\begin{array}{l}\text { No, authors do not link } \\
\text { adverse events to } \\
\text { endoscopy }\end{array}$ \\
\hline Malignancy [28-32] & 5 & $\begin{array}{l}\text { Maternal death } \\
(n=1) \text {, none } \\
(n=4)\end{array}$ & Live birth $(n=5)$ & No $(n=5)$ & $\begin{array}{l}3 \text { premature births } \\
(33,33.6 \text { and } 34 \text { wks) }\end{array}$ & No & No \\
\hline Volvulus and incarcerated uterus & 0 & - & - & - & - & - & - \\
\hline Non-malignant colonic obstruction [33] & 1 & None & Live birth $(n=1)$ & No $(n=1)$ & None & No & No \\
\hline Gastrointestinal bleeding $[34,35]$ & 3 (in 2 pts) & None & Live birth $(n=2)$ & No $(n=2)$ & None & No & No \\
\hline Total & 32 & & & & & & \\
\hline
\end{tabular}

$\mathrm{IBD}=$ Inflammatory Bowel Disease. 
Table 2 Second trimester fetal and maternal adverse events (wk 13-26)

\begin{tabular}{|c|c|c|c|c|c|c|c|}
\hline Indication & $\mathrm{N}$ & Maternal adverse events & $\begin{array}{l}\text { Pregnancy } \\
\text { outcome }\end{array}$ & Premature births & $\begin{array}{l}\text { Other fetal adverse } \\
\text { events }\end{array}$ & $\begin{array}{l}\text { Temporal relation with } \\
\text { endoscopy? }\end{array}$ & $\begin{array}{l}\text { Etiological relation with } \\
\text { endoscopy? }\end{array}$ \\
\hline \multicolumn{8}{|l|}{ Sigmoidoscopy } \\
\hline IBD \& colitis other [36-41] & 8 (in 6 pts) & None $(n=6)$ & $\begin{array}{l}\text { Live birth }(n=5) \text {, } \\
\text { not reported }(n=1)\end{array}$ & $\begin{array}{l}\text { Yes }(n=1) \\
\text { no }(n=4) \\
\text { not reported } \\
(n=1)\end{array}$ & $\begin{array}{l}\text { Low birth weight } \\
(n=2) \text {, not reported } \\
(n=1)\end{array}$ & No & No \\
\hline Malignancy [42-47] & 6 & $\begin{array}{l}\text { Maternal death } \\
(n=2) \text {, unreported } \\
(n=1) \text {, none }(n=3)\end{array}$ & $\begin{array}{l}\text { Live birth }(n=3) \text {, } \\
\text { elective abortion } \\
(n=2) \text {, fetal death } \\
(n=1)\end{array}$ & $\begin{array}{l}\text { Yes }(n=3) \text { all } \\
\text { prostaglandin } \\
\text { induced or elective } \\
\text { caesarean section }\end{array}$ & Low birth weight $(n=3)$ & Yes $(n=3)$, no $(n=3)$ & Unlikely $(n=3)$ \\
\hline $\begin{array}{l}\text { Volvulus and incarcerated } \\
\text { uterus }[19,48,49]\end{array}$ & 7 (in 5 pts) & None & Live birth $(n=5)$ & None & Low birth weight $(n=1)$ & No & No \\
\hline $\begin{array}{l}\text { Non-malignant colonic } \\
\text { obstruction [50] }\end{array}$ & 1 & None & Live birth $(n=1)$ & Yes $(n=1)$ & Vaginal delivery at 35 wks & No & No \\
\hline Gastrointestinal bleeding [51] & 1 & None & Stillbirth $(n=1)$ & Yes $(n=1)$ & $\begin{array}{l}\text { Fetal demise at } 20 \text { wks } \\
\text { within several hours of } \\
\text { surgery }\end{array}$ & Yes & $\begin{array}{l}\text { Possible, however the } \\
\text { patient also underwent } \\
\text { emergency surgery and } \\
\text { suffered from a massive } \\
\text { hemorrhage }\end{array}$ \\
\hline \multicolumn{8}{|l|}{ Colonoscopy } \\
\hline IBD \& colitis other [24,52-54] & 6 & None & $\begin{array}{l}\text { Live birth }(n=5) \text {, } \\
\text { stillbirth }(n=1)\end{array}$ & $\begin{array}{l}\text { Yes }(n=2) \\
\text { No }(n=4)\end{array}$ & $\begin{array}{l}\text { Unreported }(n=2) \text {, } \\
\text { none }(n=4)\end{array}$ & $\begin{array}{l}\text { Unclear, paper fails to } \\
\text { show which outcome } \\
\text { belongs to which patient }\end{array}$ & $\begin{array}{l}\text { Unclear, authors do not link } \\
\text { adverse event (stillbirth) to } \\
\text { endoscopy }\end{array}$ \\
\hline Malignancy [55-60] & 6 & $\begin{array}{l}\text { None }(n=3), \\
\text { maternal death } \\
\text { postpartum }(n=2) \text {, } \\
\text { disease progression } \\
\text { postpartum }(n=1)\end{array}$ & $\begin{array}{l}\text { Live birth }(n=4) \text {, } \\
\text { unreported }(n=1) \text {, } \\
\text { fetal death at } \\
26 \text { wks }(n=1)\end{array}$ & $\begin{array}{l}\text { Yes }(n=3) \\
\text { at } 30,34 \\
\text { and } 36 \text { wks }\end{array}$ & $\begin{array}{l}\text { Low birth weight } \\
(n=3) \text {, neonatal } \\
\text { care unit admittance } \\
\text { postpartum }(n=2)\end{array}$ & $\begin{array}{l}\text { Yes, fetal death was } \\
\text { within } 1 \text { week of } \\
\text { colonoscopy, premature } \\
\text { births no temporal } \\
\text { relation with endoscopy }\end{array}$ & $\begin{array}{l}\text { Probable, but fetal death } \\
\text { most likely due to maternal } \\
\text { deterioration because of } \\
\text { cancer progression and sepsis }\end{array}$ \\
\hline $\begin{array}{l}\text { Volvulus and incarcerated } \\
\text { uterus [61] }\end{array}$ & 1 & Not reported & Live birth $(n=1)$ & No & None & No & No \\
\hline $\begin{array}{l}\text { Non-malignant colonic } \\
\text { obstruction [62] }\end{array}$ & 1 & $\begin{array}{l}\text { Mother remained } \\
\text { hospitalized for } \\
50 \text { days after delivery }\end{array}$ & Stillbirth $(n=1)$ & Yes $(n=1)$ & $\begin{array}{l}\text { Evidence of spontaneous } \\
\text { labour, physicians terminated } \\
\text { the pregnancy at } 15 \text { wks }\end{array}$ & Yes & $\begin{array}{l}\text { Probable, however colonic } \\
\text { perforation was feared due } \\
\text { to worsening distention of } \\
\text { the bowel, not per se due } \\
\text { to the LGE }\end{array}$ \\
\hline $\begin{array}{l}\text { Gastrointestinal bleeding } \\
{[34,63]}\end{array}$ & 2 & None $(n=2)$ & $\begin{array}{l}\text { Live birth }(n=1) \text {, } \\
\text { not reported }(n=1)\end{array}$ & $\begin{array}{l}\text { No }(n=1) \text {, not } \\
\text { reported }(n=1)\end{array}$ & $\begin{array}{l}\text { Not reported }(n=1) \\
\text { None }(n=1)\end{array}$ & No & No \\
\hline Total & 39 & & & & & & \\
\hline
\end{tabular}


Table 3 Third trimester fetal and maternal complications (27-42 wks)

\begin{tabular}{|c|c|c|c|c|c|c|c|}
\hline Indication & $\mathrm{N}$ & Maternal adverse events & Pregnancy outcome & Premature birth & Fetal adverse events & $\begin{array}{l}\text { Temporal relation } \\
\text { with endoscopy? }\end{array}$ & $\begin{array}{l}\text { Etiological relation with } \\
\text { endoscopy? }\end{array}$ \\
\hline \multicolumn{8}{|l|}{ Sigmoidoscopy } \\
\hline IBD \& colitis other $[11,64,65]$ & 3 & $\begin{array}{l}\text { None }(n=2) \text {, subtotal } \\
\text { colectomy with } \\
\text { ileostomy after } \\
\text { delivery }(n=1)\end{array}$ & Live birth $(n=3)$ & $\begin{array}{l}\text { No }(n=1) \\
\text { Yes }(n=2)\end{array}$ & $\begin{array}{l}\text { Premature births ( } 28 \text { and } \\
34 \text { wks), low birth weight } \\
(1850 \text { and } 1054 \mathrm{~g})\end{array}$ & $\begin{array}{l}\text { No }(n=2) \\
\text { yes }(n=1)\end{array}$ & $\begin{array}{l}\text { Likely, after sigmoidoscopy } \\
\text { colonic perforation was } \\
\text { suspected, this led to an } \\
\text { emergency caesarean } \\
\text { section. }\end{array}$ \\
\hline Malignancy [66-70] & 5 & $\begin{array}{l}\text { Not reported }(n=3) \text {, } \\
\text { death } 12 \text { months after } \\
\text { hemicolectomy }(n=1) \text {, } \\
1,5 \text { years after delivery } \\
\text { discovery of pulmonary } \\
\text { metastases }(n=1)\end{array}$ & Live birth $(n=5)$ & $\begin{array}{l}\text { Yes }(n=4) \\
\text { No }(n=1)\end{array}$ & $\begin{array}{l}\text { Premature births at } 34,34, \\
31 \text { and } 33 \text { wks, all deliveries } \\
\text { were elective, low birth } \\
\text { weight reported }(n=2)\end{array}$ & No & Unlikely \\
\hline $\begin{array}{l}\text { Volvulus and incarcerated } \\
\text { uterus }[49,71-73]\end{array}$ & 5 (in 4 pts) & None & Live birth $(n=4)$ & None & None & Yes $(n=1)$ & Unlikely \\
\hline $\begin{array}{l}\text { Non-malignant colonic } \\
\text { obstruction }[74,75]\end{array}$ & 2 & None & $\begin{array}{l}\text { Live birth }(n=1) \\
\text { not reported }(n=1)\end{array}$ & Yes $(n=1)$ & $\begin{array}{l}\text { Elective caesarean section } \\
(n=1), \text { Not reported }(n=1)\end{array}$ & Yes $(n=1)$ & Unlikely \\
\hline Gastrointestinal bleeding & 0 & - & - & - & - & - & - \\
\hline \multicolumn{8}{|l|}{ Colonoscopy } \\
\hline IBD \& colitis other $[52,76]$ & 2 & $\begin{array}{l}\text { Intensive care unit } \\
\text { admittance postpartum } \\
(n=1) \text {, none }(n=1)\end{array}$ & $\begin{array}{l}\text { Live birth }(n=1) \\
\text { not reported }(n=1)\end{array}$ & $\begin{array}{l}\text { Yes }(n=1) \text {, not } \\
\text { reported }(n=1)\end{array}$ & $\begin{array}{l}\text { Premature birth ( } 32 \text { wks) } \\
\text { with low birth weight } \\
2175 \text { grams }\end{array}$ & No & Unlikely \\
\hline Malignancy [77-84] & 8 & $\begin{array}{l}\text { None }(n=4) \text {, maternal } \\
\text { death after delivery } \\
\text { due to disease } \\
\text { progression }(n=4)\end{array}$ & Live birth $(n=8)$ & Yes $(n=8)$ & $\begin{array}{l}\text { Premature births by elective } \\
\text { caesarean section }(n=4) \text {, } \\
\text { spontaneous premature } \\
\text { birth }(n=4)\end{array}$ & $\begin{array}{l}\text { Yes }(n=1) \\
\text { no }(n=7)\end{array}$ & Unlikely \\
\hline Volvulus and incarcerated uterus & 0 & - & - & - & - & - & - \\
\hline $\begin{array}{l}\text { Non-malignant colonic } \\
\text { obstruction }[85,86]\end{array}$ & 3 (in 2 pts) & None & $\begin{array}{l}\text { Live birth }(n=1) \text {, } \\
\text { live twin birth }(n=1)\end{array}$ & Yes $(n=1)$ & $\begin{array}{l}\text { Spontaneous premature } \\
\text { birth of twins at wk } 34\end{array}$ & Yes & $\begin{array}{l}\text { Possible, however nifedipine } \\
\text { was also stopped around } \\
\text { time of LGE }\end{array}$ \\
\hline Gastrointestinal bleeding [87] & 1 & None & $\begin{array}{l}\text { Elective termination } \\
\text { at } 34 \text { wks }\end{array}$ & Yes & Not reported & No & Unlikely \\
\hline Total & 29 & & & & & & \\
\hline
\end{tabular}


Table 4 Summary of adverse events (AEs) etiologically related to LGE

\begin{tabular}{cllll}
\hline Week of LGE & Week of AE & Type of AE & Other intervention between LGE and AE & Likeliness relation \\
\hline $\begin{array}{clll}\text { Sigmoidoscopy } \\
10\end{array}$ & 10.4 & Incomplete spontaneous abortion & Laparotomy & Possible \\
20 & 20 & Fetal death & Laparotomy & Possible \\
28 & 28 & $\begin{array}{l}\text { Suspected perforation leading to } \\
\text { emergency caesarean section }\end{array}$ & $\begin{array}{l}\text { Laparotomy and caesarean } \\
\text { section at same time }\end{array}$ & Likely \\
Colonoscopy & & Fetal death & None & Probable \\
25 & 26 & Pregnancy termination by physicians & None & Probable \\
15.2 & 15.3 & Premature spontaneous labour & Nifedipine cessation & Possible \\
34.0 & 34.1 &
\end{tabular}

three fetal deaths within one week of endoscopy. In the first case [51], the patient suffered from massive hematochezia due to multiple bleeding foci in the cecum and terminal ileum and underwent laparotomy shortly after colonoscopy. Fetal demise was evident several hours after surgery. This adverse event is possibly related to the LGE. The second patient was diagnosed with an advanced stage of colorectal carcinoma with liver metastases and ascites during pregnancy. After colonoscopy, the patient deteriorated rapidly and seven days after endoscopy fetal death was observed by ultrasonography. The mother died within 2 weeks after delivery [55]. This adverse event can probably be related to the LGE. The third case demonstrated a patient with progressive colonic distension caused by colonic pseudo-obstruction (Ogilvie's syndrome). After colonoscopy, radiologic studies showed no evidence of colonic perforation, but the day after colonoscopy the abdominal distension progressed further, the patient went into spontaneous labor and the physicians decided to terminate the pregnancy [62]. This adverse event could also probably be related to the LGE. Two patients diagnosed with colorectal adenocarcinoma during pregnancy underwent elective abortion within one week of LGE in gestational week 16 and $20[42,43]$ and in one patient labor was induced with prostaglandin in gestational week 26 [44]. These three adverse events were therefore classified as unlikely related to the LGE.

\section{Third trimester}

In the third trimester, 27 patients underwent 29 endoscopies. All complications following LGE in the third trimester are listed in Table 3. Four case reports demonstrated adverse events within one week of endoscopy. These four cases were likely related in one, possibly related in one and unlikely related in two of the cases. The first case describes a patient who was diagnosed with ulcerative colitis upon sigmoidoscopy in the sixth week of pregnancy. In the 28th week of pregnancy she exhibited signs of exacerbation and she underwent another sigmoidoscopy with biopsies. Following the second sigmoidoscopy, colonic perforation was suspected and an emergency caesarean section and exploratory laparotomy was performed. No colonic perforation was seen intraoperatively [11]. A live, healthy baby of $1054 \mathrm{~g}$ was delivered. This adverse event was classified as likely to be related to the LGE. The second patient was 33 weeks pregnant with twins, when she underwent two subsequent colonoscopies for the treatment and decompression of acute colonic pseudo-obstruction. She was already being treated with nifedipine upon presentation for inhibition of premature contractions, and nifedipine was stopped upon hospital admission. One day after the last colonoscopy at gestational week 34, she went into spontaneous labor and delivered healthy twins [85]. This adverse event is possibly related to the LGE. The third patient underwent sigmoidoscopy because of abdominal pain and distention in the 34th gestational week. Upon endoscopy, the splenic flexure appeared necrotic and the patient immediately underwent laparotomy with an emergency caesarean section [74]. This adverse event is unlikely related to the LGE. The fourth patient was diagnosed with a malignancy of unknown origin, and in the metastatic workup a colonoscopy was performed in gestational week 32. A poorly differentiated signet cell adenocarcinoma of the transverse colon was found, and after 4 days of dexamethasone administration for fetal lung maturation an elective caesarean section was performed [77]. This adverse event was unlikely related to the LGE.

One case report and one case series did not report at what gestational week the LGE was performed and were therefore not categorized. These case reports describe three pregnant women with IBD who underwent sigmoidoscopy for IBD disease assessment. One woman delivered a live baby of 1008 gram prematurely at 28.1 weeks [88]. A temporal relation was not found, and the authors do not link this adverse event to the sigmoidoscopy. In the case series, 2 out of 5 women underwent sigmoidoscopy, and one woman delivered a live baby prematurely. It is not reported if this woman underwent LGE [89]. 


\section{Sensitivity analysis}

A sensitivity analysis was performed by elongating the time span for the temporal relation between adverse events and the LGE. Initially, all adverse events were temporally related to the LGE if they occurred within one week after the LGE, however this analysis will classify all adverse events within three weeks of the LGE as temporally related. In the first trimester, this approach yielded no extra temporally related adverse events. In the second trimester, one additional temporally related adverse event was detected. In this case, the mother was diagnosed with advanced colorectal carcinoma during pregnancy and died together with the fetus two weeks after hospital admission around gestational week 23 [45]. This adverse event was unlikely to be related to the LGE. Finally, in the third trimester another seven temporally related adverse events were detected. Six premature deliveries were unlikely related to the LGE, as they were all elective caesarean sections [76,78-80,87] or induced labor [66]. The seventh patient suffered from ulcerative colitis and underwent LGE for assessment of disease activity in gestational week 32. Endoscopy showed the colon to be severely inflamed and two weeks later the patient delivered a premature baby of 1850 grams [64]. This adverse event is classified as probably related to the LGE.

\section{Discussion}

The objective of this systematic review was to assess the risk of LGE in all trimesters of pregnancy.

Three retrospective cohort studies investigated the safety of LGE during pregnancy. Of these, two studies describe the same study population, and report no difference in birth outcomes and adverse events between the study and the control group. None of the reported fetal and maternal adverse events showed a temporal or an etiological relation with the LGE $[8,10]$. Although these studies report no adverse events related to LGE, it remains unclear in which trimester the LGE was performed.

The third study [3], on which the recent endoscopy guidelines [9] seem to be based, focuses exclusively on colonoscopies during pregnancy. The authors conclude that colonoscopies during pregnancy are probably safe to perform, but limit their conclusion to the second trimester because of insufficient data in the first and third trimester. Prior to this study in 2010, the authors identified 17 case reports on colonoscopy during pregnancy and add these data to their own conclusion that there is still insufficient evidence to claim safety of colonoscopy in each trimester [3].

Overall, this systematic review identified 79 case reports, describing 100 LGE's in 92 patients. In total six $(6.0 \%)$ temporally and etiologically related adverse events were found.
Out of these 79 case reports 42 case reports described 51 colonoscopies in 49 patients during pregnancy, distributed equally across the trimesters $(21,16$ and 14 colonoscopies in trimester 1,2 and 3, respectively). Three temporally and etiologically related adverse events occurred in these 49 patients (6.1\%), of which 1 occurred in the third trimester [85] and was possibly related and 2 occurred in the second trimester [55,62] and were probably related to the colonoscopy (see Table 2 and 3). Although the evidence level of these case reports is low, these data suggest colonoscopy during pregnancy is probably safe to perform. This finding is in agreement with the primary conclusion of the included studies. However, the data from our included case reports in fact suggests colonoscopy to be of similar low risk in each trimester. In addition, we identified 37 case reports, describing 49 sigmoidoscopies in 43 patients. In this subset of patients, also three temporally and etiologically related adverse events occurred in these 43 patients (7.0\%), of which one occurred in the first [20] and one in the second trimester [51] and were both possibly related, and one in the third trimester [11] and was likely related to the sigmoidoscopy.

Furthermore, in our view, postponing LGE during pregnancy or even until after pregnancy might hamper the patient and the pregnancy more than the LGE itself. A diagnostic delay will inevitably induce an unwanted therapeutic delay, and therefore the risks of LGE during pregnancy must be weighed against the expected benefits. Consequently, elective endoscopies (e.g. for screening purposes) should be deferred until after pregnancy.

Safety research during pregnancy is always a challenging field, as prospective studies are rarely, and experimental studies are almost never performed. Therefore, we rely on retrospective studies and case series to support our conclusions and guidelines. Although the evidence in this systematic review is anecdotal and more controlled studies are needed, this review appears to be the most extensive overview of available studies on this subject.

The major limitation of this exhaustive systematic review is the lacking of a solid control group for the summarized case reports. Furthermore, the majority of case reports describe severely ill patients in whom the true effect of LGE during pregnancy is hard to untangle. In addition, none of the case reports primarily aimed to describe the effect of LGE during pregnancy, rendering these effects subject to our interpretation. Type of bowel preparation and sedation are not mentioned in the majority of included case reports, and their effects cannot be taken into consideration. Also, mild and more subtle adverse events due to LGE could have been easily missed. We therefore focused on serious adverse events like spontaneous abortion, stillbirth and premature delivery. 


\section{Conclusion}

In conclusion, we underline that LGE should only be performed during pregnancy when strongly indicated and is probably of low risk. Postponing LGE during pregnancy to the second trimester or puerperium however, is unnecessary and in most cases unwanted because of the therapeutic delay which might hamper the pregnancy outcomes more than the LGE itself.

\section{Additional file}

\section{Additional file 1: Search strategy.}

\section{Competing interests}

Disclosure information

Declaration of personal interests:

A. De Lima: none

B. Galjart: none

P.H.A. Wisse: none

W.M. Bramer: none

Dr C. J. van der Woude has served as a speaker and a consultant for Abbot, Abbvie, MSD and as a consultant for Shire.

Declaration of funding interests: None.

\section{Authors' contributions}

$A D L$ first reviewer and author, project coordinator. BG second reviewer, creation of flowchart. PHAW second reviewer, creation of flowchart. WMB performed the systematic literature search in all literature databases. CJW project initiator and supervisor, third reviewer, adjusted the manuscript. All authors read and approved the final manuscript.

\section{Author details}

1Department of Gastroenterology and Hepatology, Erasmus MC - University Medical Center Rotterdam, 's Gravendijkwal 230, Room Hs-306, 3015 CE Rotterdam, The Netherlands. ${ }^{2}$ Medical Library, Erasmus MC - University Medical Center Rotterdam, Rotterdam, The Netherlands.

Received: 7 October 2014 Accepted: 29 January 2015

Published online: 12 February 2015

\section{References}

1. Whitlock EP, Lin JS, Liles E, Beil TL, Fu R. Screening for colorectal cancer: a targeted, updated systematic review for the U.S. Preventive Services Task Force. Ann Intern Med. 2008;149:638-58.

2. Chukmaitov A, Bradley CJ, Dahman B, Siangphoe U, Warren JL, Klabunde CN. Association of polypectomy techniques, endoscopist volume, and facility type with colonoscopy complications. Gastrointest Endosc. 2013;77:436-46

3. Cappell MS, Fox SR, Gorrepati N. Safety and efficacy of colonoscopy during pregnancy: an analysis of pregnancy outcome in 20 patients. J Reprod Med. 2010;55:115-23.

4. Cappell MS. The fetal safety and clinical efficacy of gastrointestinal endoscopy during pregnancy. Gastroenterol Clin North Am. 2003;32:123-79.

5. DiSario JA, Waring JP, Talbert G, Sanowski RA. Monitoring of blood pressure and heart rate during routine endoscopy: a prospective, randomized, controlled study. Am J Gastroenterol. 1991;86:956-60.

6. Cappell MS, Sidhom O. A multicenter, multiyear study of the safety and clinical utility of esophagogastroduodenoscopy in 20 consecutive pregnant females with follow-up of fetal outcome. Am J Gastroenterol. 1993:88:1900-5.

7. Cappell MS, Colon VJ, Sidhom OA. A study of eight medical centers of the safety and clinical efficacy of esophagogastroduodenoscopy in 83 pregnant females with follow-up of fetal outcome with comparison control groups. Am J Gastroenterol. 1996;91:348-54.

8. Cappell MS, Colon VJ, Sidhom OA. A study at 10 medical centers of the safety and efficacy of 48 flexible sigmoidoscopies and 8 colonoscopies during pregnancy with follow-up of fetal outcome and with comparison to control groups. Dig Dis Sci. 1996;41:2353-61.

9. Committee ASoP, Shergill AK, Ben-Menachem T, Chandrasekhara V, Chathadi K, Decker GA, et al. Guidelines for endoscopy in pregnant and lactating women. Gastrointest Endosc. 2012;76:18-24.

10. Cappell MS, Sidhom O. Multicenter, multiyear study of safety and efficacy of flexible sigmoidoscopy during pregnancy in 24 females with follow-up of fetal outcome. Dig Dis Sci. 1995;40:472-9.

11. Haq Al, Sahai A, Hallwoth S, Rampton DS, Dorudi S. Synchronous colectomy and caesarean section for fulminant ulcerative colitis: case report and review of the literature. Int J Colorectal Dis. 2006;21:465-9.

12. Ates $Y$, Aslan M, Tuzun A, Bagci S, Dagalp K. Ulcerative colitis case beginning during pregnancy in a patient with antiphospholipid antibody syndrome. Turk J Gastroenterol. 2004;15:263-5.

13. Jayaprakash A, Gould S, Lim AG, Shehata HA. Use of cyclosporin in pregnancy. Gut. 2004;53:1386-7.

14. Coburn LA, Wise PE, Schwartz DA. The successful use of adalimumab to treat active Crohn's disease of an ileoanal pouch during pregnancy. Dig Dis Sci. 2006:51:2045-7.

15. Reindl W, Schmid RM, Huber W. Cyclosporin A treatment of steroid-refractory ulcerative colitis during pregnancy: report of two cases. Gut. 2007:56:1019.

16. Aratari A, Margagnoni $G$, Koch M, Papi C. Intentional infliximab use during pregnancy for severe steroid-refractory ulcerative colitis. J Crohns Colitis. 2011:5:262.

17. Hitti IF, Glasberg SS, Lubicz S. Clear cell carcinoma arising in extraovarian endometriosis: report of three cases and review of the literature. Gynecol Oncol. 1990;39:314-20.

18. Parsa L, Bijpuria P, Ringold D, Stein D. A rare case of myeloid sarcoma presenting as an anorectal ulcer. Case Rep Med. 2012:2012:537278.

19. Seubert DE, Puder KS, Goldmeier P, Gonik B. Colonoscopic release of the incarcerated gravid uterus. Obstet Gynecol. 1999;94:792-4.

20. Fisch B, Powsner E, Heller L, Goldman GA, Tadir Y, Wolloch J, et al. Heterotopic abdominal pregnancy following in-vitro fertilization/embryo transfer presenting as massive lower gastrointestinal bleeding. Hum Reprod. 1995;10:681-2

21. Okamoto Y, Fujii M, Tateiwa S, Sakai T, Ochi F, Sugano M, et al. A case of ischemic colitis during pregnancy. J Gastroenterol. 2003;38:1195-7.

22. Toiyama Y, Araki T, Yoshiyama S, Sakamoto N, Miki C, Kusunoki M. Fulminan ulcerative colitis during pregnancy successfully treated by three-stage operation. J Gastroenterol. 2004;39:300-1.

23. Okada H, Makidono C, Takenaka R, Hiraoka S, Fujiwara A, Kato J, et al. Therapeutic efficacy of leukocytapheresis in a pregnant woman with severe active ulcerative colitis. Digestion. 2006;74:15-8.

24. Branche J, Cortot A, Bourreille A, Coffin B, de Vos M, de Saussure P, et al. Cyclosporine treatment of steroid-refractory ulcerative colitis during pregnancy. Inflamm Bowel Dis. 2009;15:1044-8.

25. Arai K, Takeuchi Y, Oishi C, Imawari M. The impact of disease activity of Crohn's disease during pregnancy on fetal growth. Clin J Gastroenterol. 2010;3:179-81

26. Mizoshita T, Tanida S, Tsukamoto H, Ozeki K, Katano T, Ebi M, et al. Maintenance of the remission stage of Crohn's disease with adalimumab therapy during pregnancy. Intern Med. 2013;52:1049-53.

27. Takahashi H, Sugawara K, Sugimura M, Iwabuchi M, Mano Y, Ukai K, et al. Flare up of ulcerative colitis during pregnancy treated by adsorptive granulocyte and monocyte apheresis: therapeutic outcomes in three pregnant patients. Arch Gynecol Obstet. 2013;288:341-7.

28. Gensheimer M, Jones CA, Graves CR, Merchant NB, Lockhart AC. Administration of oxaliplatin to a pregnant woman with rectal cancer. Cancer Chemother Pharmacol. 2009;63:371-3.

29. Jeppesen JB, Osterlind K. Successful twin pregnancy outcome after in utero exposure to FOLFOX for metastatic colon cancer: a case report and review of the literature. Clin Colorectal Cancer. 2011;10:348-52.

30. Hawa N, Robinson J, Obias V. Cystically degenerated leiomyoma of the rectosigmoid managed laparoscopically at 13 weeks of gestation. J Minim Invasive Gynecol. 2012;19:383-5.

31. Yamaguchi $M$, Tashiro $H$, Motohara $K$, Ohba $T$, Katabuchi $H$. Primary strumal carcinoid tumor of the ovary: A pregnant patient exhibiting severe constipation and CEA elevation. Gynecol Oncol Case Rep. 2012;4:9-12.

32. Correa DS, Lopes A, Ferreira Fd FO, Nakagawa WT, Rossi BM. Sigmoid cancer adherent to the uterus during pregnancy: case report. Colorectal Dis. 2002;4:216. 
33. Rozen P, Schreiber L, Brazowski E. Endometriosis, pregnancy, and colonoscopy. Endoscopy. 2003;35:975.

34. Kanai M, Noike M, Masaki C, Kita N, Ashida T, Kobayashi T, et al. Severe gastrointestinal bleeding during pregnancy in a case of blue rubber bleb nevus syndrome. Semin Thromb Hemost. 2005;31:284-9.

35. Hogan RB, Ahmad N, Hogan 3rd RB, Hensley SD, Phillips P, Doolittle P, et al. Video capsule endoscopy detection of jejunal carcinoid in life-threatening hemorrhage, first trimester pregnancy. Gastrointest Endosc. 2007;66:205-7.

36. Morton MR. Inflammatory bowel disease presenting in pregnancy. Aust N Z J Obstet Gynaecol. 1992:32:40-2.

37. Lortholary O, Perronne C, Leport J, Leport C, Vilde JL. Primary cytomegalovirus infection associated with the onset of ulcerative colitis. Eur J Clin Microbiol Infect Dis. 1993;12:570-2.

38. Boulton R, Hamilton M, Lewis A, Walker P, Pounder R. Fulminant ulcerative colitis in pregnancy. Am J Gastroenterol. 1994;89:931-3.

39. Ishijima N, Ojima E, Tonouchi H, Suzuki H, Fukunishi S. Delivery of a norma newborn after intensive medical treatment for an acute exacerbation of ulcerative colitis during pregnancy: a case report. Surg Today. 1999;29:1257-9.

40. Munchar J, Rahman HA, Zawawi MM. Localized giant pseudopolyposis in ulcerative colitis. Eur J Gastroenterol Hepatol. 2001;13:1385-7.

41. de Jonge HJ, Oosterwijk PR, Meijssen M, Flierman A. Rectal bleeding during pregnancy. Ned Tijdschr Geneeskd. 2014;158:A6758.

42. Minter A, Malik R, Ledbetter L, Winokur TS, Hawn MT, Saif MW. Colon cancer in pregnancy. Cancer Control. 2005;12:196-202.

43. Toosi M, Moaddabshoar L, Malek-Hosseini SA, Sasani MR, Mokhtari M, Mohammadianpanah M. Rectal cancer in pregnancy: A diagnostic and therapeutic challenge. J Egypt Natl Cancer Inst. 2014;3:175-9.

44. Neal AJ, Oliver RT, Savage W. Accelerated malignant disease in pregnancy. Br J Clin Pract. 1993;47:228

45. Araujo Junior E, Campanharo FF, Sun SY, Nardozza LMM, Mattar R, Moron AF. Fulminant adenocarcinoma of the rectum with hepatic metastasis in a young pregnant woman: A case report. Case Rep Oncol. 2012;5:208-11.

46. Gard GB, Peek MJ. Rectal carcinoma in pregnancy. Aust New Zealand J Obstet Gynaecol. 1996;36:161-4.

47. Caforio L, Draisci G, Ciampelli M, Rossi B, Sollazzi L, Caruso A. Rectal cancer in pregnancy: a new management based on blended anesthesia and monitoring of fetal well being. Eur J Obstet Gynecol Reprod Biol. 2000;88:71-4.

48. Dierickx I, Van Holsbeke C, Mesens T, Gevers A, Meylaerts L, Voets W, et al. Colonoscopy-assisted reposition of the incarcerated uterus in mid-pregnancy: a report of four cases and a literature review. Eur J Obstet Gynecol Reprod Biol. 2011;158:153-8.

49. Ahmad A, Shing KK, Tan KK, Krasu M, Bickle I, Chong VH. Sigmoid volvulus in pregnancy: early diagnosis and intervention are important. Am J Emerg Med. 2014;32:491. e491-492.

50. Curtis RD, Sweeney WB, Denobile JW, Hurwitz E. Kock pouch dysfunction during pregnancy. Management of a case. Surg Endosc. 1996;10:755-7.

51. Bashir RM, Montgomery EA, Gupta PK, Nauta RM, Crockett SA, Collea JV, et al. Massive gastrointestinal hemorrhage during pregnancy caused by ectopic decidua of the terminal ileum and colon. Am J Gastroenterol. 1995;90:1325-7.

52. Frossard JL, Spahr L, Queneau PE, Armenian B, Brundler MA, Hadengue A. Ischemic colitis during pregnancy and contraceptive medication. Digestion. 2001;64:125-7.

53. Best J, Dechene A, Esser S, Gerken G, Canbay A. Pregnancy-associated Sweet's syndrome in an acute episode of ulcerative colitis. Z Gastroenterol. 2009:47:753-7.

54. Mridula T, Pai RR, Mathai AM, Tantry BV, Adhikari P. Pseudomembranous colitis in a pregnant woman. Kathmandu Univ Med J (KUMJ). 2010;8:345-7.

55. Gonsoulin W, Mason B, Carpenter Jr RJ. Colon cancer in pregnancy with elevated maternal serum alpha-fetoprotein level at presentation. Am J Obstet Gynecol. 1990;163:1172-3.

56. Rojansky N, Shushan A, Livni N, Jurim O, Sulam M, Galun E. Pregnancy associated with colon carcinoma overexpressing p53. Gynecol Oncol. 1997;64:516-20.

57. Kanate AS, Auber ML, Higa GM. Priorities and uncertainties of administering chemotherapy in a pregnant woman with newly diagnosed colorectal cancer. J Oncol Pharm Pract. 2009;15:5-8.

58. Cirillo M, Musola M, Cassandrini PA, Lunardi G, Venturini M. Irinotecan during pregnancy in metastatic colon cancer. Tumori. 2012;98:155e-7.
59. Bukhari Y, Hogan NM, Pomeroy M, O'Leary M, Joyce MR. Surgical management of rectal cancer in pregnancy. Int J Colorectal Dis. 2013;28:883-4.

60. Dogan NU, Tastekin D, Kerimoglu OS, Pekin A, Celik C. Rectal cancer in pregnancy: a case report and review of the literature. J Gastrointest Cancer. 2013:44:354-6.

61. Montes H, Wolf J. Cecal volvulus in pregnancy. Am J Gastroenterol. 1999;94:2554-6.

62. Kim TH, Lee HH, Chung SH. Constipation during pregnancy: when a typical symptom heralds a serious disease. Obstet Gynecol. 2012;119:374-8.

63. Bural GG, Scheetz M, Laymon CM, Mountz JM. Tc-99 m red blood cell bleeding scan in a pregnant woman presenting with hematemesis: a brief review of indications and guidelines for radionuclide scans during pregnancy. Clin Nucl Med. 2011;36:987-90.

64. Friedman S. Management of inflammatory bowel disease during pregnancy and nursing. Semin Gastrointest Dis. 2001;12:245-52.

65. Diepersloot RJ, Kroes AC, Visser W, Jiwa NM, Rothbarth PH. Acute ulcerative proctocolitis associated with primary cytomegalovirus infection. Arch Intern Med. 1990;150:1749-51.

66. Ochshorn Y, Kupferminc MJ, Lessing JB, Pausner D, Geva E, Daniel Y. Rectal carcinoma during pregnancy: a reminder and updated treatment protocols. Eur J Obstet Gynecol Reprod Biol. 2000;91:201-2.

67. Komurcu S, Ozet A, Ozturk B, Arpaci F, Altundag MK, Tezcan Y. Colon cancer during pregnancy. A case report. J Reprod Med. 2001;46:75-8.

68. Theodosopoulos T, Marinis A, Dafnios N, Samanideis L, Voros D, Vassiliou J, et al. Colorectal cancer emergencies during pregnancy case reports. Eur J Gynaecol Oncol. 2006;27:422-4.

69. Lolis ED, Likoudis P, Voiniadis P, Hassiakos D, Samanides L. Synchronous rectal and colon cancer caused by familial polyposis coli during pregnancy. J Obstet Gynaecol Res. 2007:33:199-202.

70. Walfisch S, Koretz M. Advanced rectal cancer in a young pregnant Bedouin woman. Dis Colon Rectum. 1998;41:527-9.

71. Allen JC. Sigmoid volvulus in pregnancy. J R Army Med Corps. 1990;136:55-6.

72. Alshawi JS. Recurrent sigmoid volvulus in pregnancy: report of a case and review of the literature. Dis Colon Rectum. 2005;48:1811-3.

73. Dray X, Hamzi L, Lo Dico R, Barranger E. Endoscopic reduction of a volvulus of the sigmoid colon in a pregnant woman. Dig Liver Dis. 2012;44:447.

74. Rausch ME, Troiano NH, Rosen T. Use of neostigmine to relieve a suspected colonic pseudoobstruction in pregnancy. J Perinatol. 2007;27:244-6.

75. Mirza MS, Mulla M, Hall RI. Large bowel obstruction in pregnancy: a rare entity, an unusual cause. Arch Gynecol Obstet. 2009;279:177-8.

76. Candiotto A, Pascoli I, Gritti A, Busato E, Dal Pozzo G. Toxic megacolon complicating a Clostridium difficile infection in a pregnant woman. J Med Microbiol. 2010;59:124-6.

77. Woods JB, Martin Jr JN, Ingram FH, Odom CD, Scott-Conner CE, Rhodes RS Pregnancy complicated by carcinoma of the colon above the rectum. Am J Perinatol. 1992;9:102-10.

78. Chan YM, Ngai SW, Lao T. Colon cancer in pregnancy. A case report. J Reprod Med. 1999;44:733-6.

79. Vitoratos N, Salamalekis E, Makrakis E, Creatsas G. Sigmoid colon cancer during pregnancy. Eur J Obstet Gynecol Reprod Biol. 2002;104:70-2.

80. Duffy A, Shia J, Klimstra D, Temple L, O'Reilly EM. Collision tumor of the large bowel in the context of advanced pregnancy and ulcerative colitis. Clin Colorectal Cancer. 2008;7:402-5.

81. Heres P, Wiltink J, Cuesta MA, Burger CW, van Groeningen CJ, Meijer S. Colon carcinoma during pregnancy: a lethal coincidence. Eur J Obstet Gynecol Reprod Biol. 1993;48:149-52.

82. Kitoh T, Nishimura S, Fukuda S, Hirabuki S, Kaganoi J, Tokunaga Y, et al. The incidence of colorectal cancer during pregnancy in Japan: report of two cases and review of Japanese cases. Am J Perinatol. 1998;15:165-71.

83. Thelmo MC, Shen EP, Shertukde S. Metastatic pulmonary adenocarcinoma to placenta and pleural fluid: clinicopathologic findings. Fetal Pediatr Pathol. 2010;29:45-56.

84. Koyama S, Tomimatsu T, Sawada K, Kanagawa T, Tsutsui T, Kimura T. Pseudomyxoma peritonei originating from colorectal cancer during pregnancy. J Obstet Gynaecol Res. 2011;37:254-8.

85. Pecha RE, Danilewitz MD. Acute pseudo-obstruction of the colon (Ogilvie's syndrome) resulting from combination tocolytic therapy. Am J Gastroenterol. 1996;91:1265-6.

86. Grossmann EM, Kaminski DL, Amon E, Longo WE. Idiopathic megarectum complicating pregnancy: report of a case. Am J Gastroenterol. 2000;95:2969-72. 
87. Prachayakul V, Aswakul P, Kachintorn U. Bleeding hepaticojejunostomy anastomotic varices successfully treated with Histoacryl injection, using single-balloon enteroscopy. Endoscopy. 2011;43(Suppl 2 UCTN):E153.

88. Mizushima T, Tanida S, Mizoshita T, Hirata Y, Murakami K, Shimura T, et al. A complicated case of tacrolimus-induced rapid remission after cesarean section in the early third trimester for refractory severe ulcerative colitis flaring in the initial period of gestation. Case Rep Gastroenterol. 2011;5:144-51.

89. Dozois EJ, Wolff BG, Tremaine WJ, Watson WJ, Drelichman ER, Carne PW, et al. Maternal and fetal outcome after colectomy for fulminant ulcerative colitis during pregnancy: case series and literature review. Dis Colon Rectum. 2006;49:64-73.

\section{Submit your next manuscript to BioMed Central} and take full advantage of:

- Convenient online submission

- Thorough peer review

- No space constraints or color figure charges

- Immediate publication on acceptance

- Inclusion in PubMed, CAS, Scopus and Google Scholar

- Research which is freely available for redistribution 